\title{
Characteristics of pregnant women at risk and relationship with type of delivery and complications
}

\author{
Características de gestantes de risco e relação com tipo de parto e complicações \\ Características de la gestante en riesgo y relación con tipo de parto y complicaciones
}

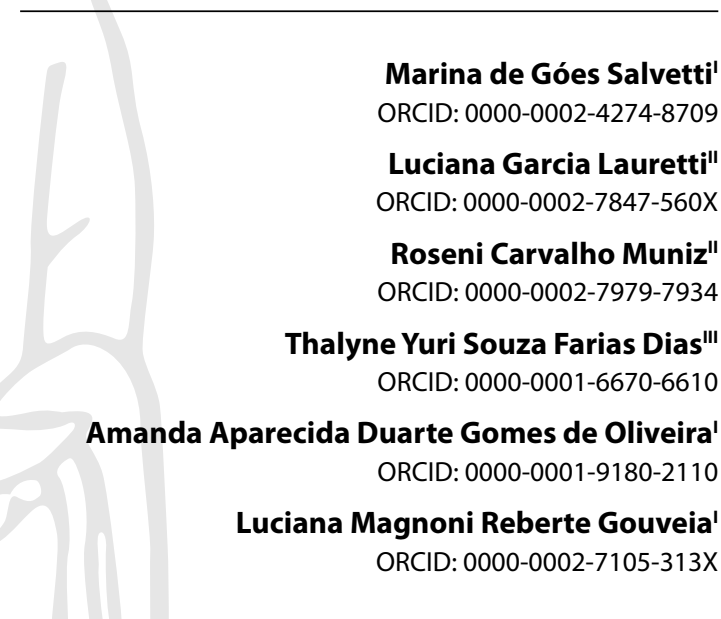

'Universidade de São Paulo. São Paulo, São Paulo, Brazil.

"AzimuteMed. São Paulo, São Paulo, Brazil.

"'Curae Caicó: Cuidado, Educação e Saúde. Caicó,

Rio Grande do Norte, Brazil.

How to cite this article:

Salvetti MG, Lauretti LG, Muniz RC, Dias TYSF, Oliveira AADG

Gouveia LMR. Characteristics of pregnant women at risk and relationship with type of delivery and complications.

Rev Bras Enferm. 2021;74(4):e20200319.

https://doi.org/10.1590/0034-7167-2020-0319

Corresponding author:

Marina de Góes Salvetti

E-mail:mgsalvetti@usp.br

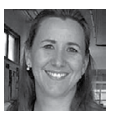

EDITOR IN CHIEF: Antonio José de Almeida Filho ASSOCIATE EDITOR: Alexandre Balsanelli

Submission: $07-20-2020$

Approval: 01-06-202

\section{ABSTRACT}

Objective: to describe characteristics of pregnant women at risk and analyze the relationship with type of delivery and complications during pregnancy and puerperium. Methods: a retrospective study with secondary data of 1,574 at-risk pregnant women followed up in an educational intervention by telemedicine. Results: pregnant women with an average age of 35 years and high educational level participated. Preference for normal delivery was $43.1 \%$, but only $17.3 \%$ had normal delivery. During pregnancy, $43.5 \%$ sought emergency care. In the postpartum period, $2.0 \%$ needed an ICU. Emergency room search was associated with age and contacts with the intervention. Cesarean delivery was associated with age, physical inactivity and overweight/obesity. ICU admission was associated with age and BMI. Conclusion: pregnant women were of high age and education, the younger and who had more contacts with the intervention sought more the emergency room. Older age, physical inactivity and overweight/obesity were factors associated with cesarean delivery. Descriptors: Prenatal Care; Pregnancy, High-Risk; Nursing; Health Promotion; Telemedicine.

\section{RESUMO}

Objetivo: descrever as características de gestantes de risco e analisar relação com tipo de parto e complicações na gestação e puerpério. Métodos: estudo retrospectivo com dados secundários de 1.574 gestantes de risco acompanhadas em intervenção educativa por telemedicina. Resultados: gestantes com idade média de 35 anos e escolaridade elevada participaram da intervenção. A preferência pelo parto normal foi de $43,1 \%$, mas apenas $17,3 \%$ tiveram parto normal. Durante a gestação, $43,5 \%$ buscaram o pronto-socorro. No pós-parto, 2,0\% necessitaram de UTI. A busca pelo pronto-socorro esteve associada à idade e contatos com a intervenção. $O$ parto cesáreo esteve associado à idade, sedentarismo e sobrepeso/obesidade. A internação em UTI esteve associada à idade e IMC. Conclusão: as gestantes tinham idade e escolaridade elevadas, as mais jovens e que tiveram mais contatos com a intervenção buscaram mais o pronto-socorro. Idade mais elevada, sedentarismo e sobrepeso/obesidade foram fatores associados ao parto cesárea.

Descritores: Cuidado Pré-Natal; Gravidez de Alto Risco; Enfermagem; Promoção da Saúde: Telemedicina.

\section{RESUMEN}

Objetivo: describir las características de las gestantes en riesgo y analizar la relación con el tipo de parto y las complicaciones durante el embarazo y el puerperio. Métodos: estudio retrospectivo con datos secundarios de 1.574 gestantes de alto riesgo seguidas en una intervención educativa por telemedicina. Resultados: participaron de la intervención gestantes con edad promedio de 35 años y estudios secundarios. La preferencia por el parto normal fue del $43,1 \%$, pero solo el $17,3 \%$ tuvo un parto normal. Durante el embarazo, el $43,5 \%$ acudió a urgencias. En el posparto, el 2,0\% necesitó una UCI. La búsqueda del servicio de urgencias se asoció con la edad y los contactos con la intervención. El parto por cesárea se asoció con la edad, la inactividad física y el sobrepeso/obesidad. El ingreso a la UCl se asoció con la edad y el IMC. Conclusión: las gestantes tenían mayor edad y educación, las más jóvenes y que tenían más contactos con la intervención acudieron más a urgencias. La edad avanzada, la inactividad física y el sobrepeso/obesidad fueron factores asociados con el parto por cesárea.

Descriptores: Atención Prenatal; Embarazo de Alto Riesgo; Enfermería; Promoción de la Salud; Telemedicine. 


\section{INTRODUCTION}

Prenatal care is essential for a positive experience in pregnancy and the puerperium by promoting respectful, individualized and woman-centered maternal care at every contact, with the implementation of effective practices and relevant information in a timely manner as well as by through emotional and psychosocial support ${ }^{(1)}$.

Despite the great advances achieved in reducing maternal mortality in recent decades, mainly with the initiatives of the Millennium Development Goals, promoted by the United Nations (UN) between 2000 and 2015, as well as with the establishment of the objectives of sustainable development until 2030, maternal mortality is still high, with around 295,000 deaths per year worldwide in $2017^{(2-4)}$.

Problems such as unequal access to health services, delay in identifying and treating complications associated with pregnancy and lack of guidance are still obstacles to overcome ${ }^{(4-5)}$. If, on the one hand, coverage for assisted births in health institutions is almost universal in Brazil, on the other hand, there is an excessive use of medicalization and surgical interventions, with high rates of births by cesarean sections ${ }^{(4)}$.

A study that analyzed the quality of prenatal care in Brazil showed that only $15 \%$ of pregnant women received qualified prenatal care, considering all the actions recommended for this type of care. Better rates were observed among older pregnant women, with higher income, from the southeast region and from municipalities with more than 300 thousand inhabitants and a higher human development index (HDI), showing the impact of social inequalities in prenatal care ${ }^{(6)}$.

A recent survey conducted in southern Brazil analyzed prenatal care for pregnant women at risk attended by the public service. The results showed adequacy of prenatal care in $74 \%$ of visits, with high coverage and early onset, but with flaws in relation to information about gestational diseases and test results ${ }^{(5)}$.

The World Health Organization (WHO) recommendations emphasize nutritional interventions, maternal and fetal assessment, preventive measures, interventions for symptoms and health interventions to improve prenatal care ${ }^{(1)}$.

Maintaining healthy lifestyle habits includes a conscious and balanced diet and the practice of physical activities in the pregnant woman's routine to avoid excessive weight gain during pregnancy. In relation to maternal assessment, the main recommendations refer to the monitoring of gestational diabetes, reduction or cessation of tobacco and other substances, HIV and syphilis, whereas in relation to the fetus, the main recommendation is to perform at least one ultrasound before the $24^{\text {th }}$ week of gestation ${ }^{(1)}$.

Preventive measures provide antibiotic therapy for women with asymptomatic bacteriuria and tetanus vaccination. Measures to relieve symptoms and discomfort in relation to nausea and vomiting, heartburn, cramps, low back and pelvic pain, constipation, edema and varicose veins should also be offered ${ }^{(1)}$.

Prenatal book use, healthy behavior promotion, nutritional supplement distribution and at least eight contacts with the health service or eight prenatal consultations are elements of qualification of prenatal care ${ }^{(1)}$.

Educational interventions for pregnant women have increased in recent years and have shown positive results through the use of educational booklets, face-to-face or telephone interventions, contributing to improving maternal-fetal mortality indicators ${ }^{(7)}$.

Nursing educational activities with pregnant women and women who have recently given birth were assessed in northeastern Brazil. An educational intervention with the use of a booklet to promote healthy eating practices has proven effective in improving the knowledge, attitudes and practices of pregnant women regarding healthy eating based on the use of regional foods ${ }^{(8)}$.

Another telephone nursing intervention with pregnant women to promote self-efficacy and exclusive breastfeeding included three telephone contacts over the course of a month. The intervention was applied by a nurse experienced in lactation to improve self-efficacy and duration of breastfeeding. There was a significant difference at two months of a baby's life in relation to the duration of breastfeeding, and at four months, with greater self-efficacy for breastfeeding ${ }^{(9)}$.

In relation to high-risk pregnant women, educational actions have shown to be limited, as assessed by an integrative review that described educational strategies for preventing pregnancy complications that did not identify studies with educational actions for high-risk pregnant women ${ }^{(7)}$.

The present study sought to explore the characteristics of pregnant women at risk participating in an educational intervention by telemonitoring and the relationship of these characteristics with the outcomes and complications related to childbirth and the puerperium.

\section{OBJECTIVE}

To describe characteristics of pregnant women at risk and analyze the relationship with type of delivery and complications during pregnancy and the puerperium.

\section{METHODS}

\section{Ethical aspects}

This study analyzed secondary data from a private health company and followed the recommendations of Resolution 510/2016 of the Brazilian National Health Council (Conselho Nacional de Saúde), which states that there is no need for submission and assessment by a Research Ethics Committee in studies with a database of aggregated information, with no possibility of individual identification of the study subjects.

\section{Design}

This is an observational, retrospective case series study with analysis of secondary data from a telemedicine program aimed at pregnant women at risk in a private health company, which followed the STROBE recommendation.

The data analyzed in this study were generated during the telephone calls of the telemedicine program, following a specific script for each session. The consultations were carried out over a year (April 2018 to April 2019). The data generated during the sessions were stored in software developed by the health company itself and subsequently extracted in the form of an Excel Program Spreadsheet 
by the information technology team, with the support of the telemedicine program's nurse manager, from August to October 2019.

The telemedicine program called "Futura Mamãe" was a program with monthly monitoring, carried out by nurses and aimed at pregnant women at risk. The Futura Mamãe Program was applied by telemonitoring and included educational strategies (applied by phone, chat, SMS, and WhatsApp), educational videos and one to three face-to-face visits with nurses or other health professionals (nutritionist or physical educator), in addition to monitoring the newborns up to 4 months of life.

The content of educational strategies included: care for a healthy pregnancy; importance of prenatal care; awareness for choosing the type of delivery; adequate nutrition; gastric discomfort and edema; preparation of the breasts; preparing for childbirth and accompanying guidance; importance of rest, general review of guidelines; preparing for childbirth and baby care (pediatrics at home).

The pregnant women were counted by telephone by the program team and those who agreed to participate received an average of 9 contacts from the "Futura Mamãe" Program. Participants could also contact the program for 24 hours (free contact via 0800) to answer questions about pregnancy or complications, whenever necessary.

The program aimed to increase the rate of normal childbirth/ reduce the rate of cesarean sections and reduce emergency room visits and reduce hospitalizations in Intensive Care Units (ICUs).

Pregnant women were considered at risk based on the following indicators: age $>35$ years, history of abortions, obesity, multiple pregnancies, previous diseases and/or diseases acquired during pregnancy (such as diabetes, pre-eclampsia and eclampsia), emotional factors and presence of bad health habits (tobacco or alcohol consumption) ${ }^{(10-11)}$.

The dependent variables or outcomes of this study were normal delivery rate/cesarean delivery rate, emergency room visits during pregnancy and rate of ICU admissions after delivery.

The independent variables were sociodemographic (age and education) and clinical (health perception, emotional data, obstetric follow-up, pregnancy complications, Body Mass Index (BMI), planned pregnancy, type of delivery you want, chronic diseases, smoking, alcoholic beverages, food, physical activity and adherence to the consultation plan.

Data analysis included descriptive and inferential statistics. Qualitative descriptive data were presented by means of frequency and percentage, quantitative data were presented as means, standard deviations, and medians. The association between qualitative variables was tested using Pearson's chi-square and Fisher's exact test. The association between quantitative variables was tested using the Brunner-Munzel, Wilcoxon-Mann-Whitney and KruskalWallis tests. For all analyzes, a significance level of $5 \%$ was adopted.

\section{RESULTS}

This study analyzed data from 1,574 pregnant women who participated in the "Futura Mamãe" Program from April 2018 to April 2019. The data were extracted from the company's database from August to October 2019. The pregnant women were 20 states of the country, with a predominance in São Paulo (69.0\%), Rio de Janeiro (13.3\%), and Minas Gerais (4.2\%).
The average age of pregnant women was 34.9 years and the average Body Mass Index (BMI) in the first trimester of pregnancy was 27.2. Participants had a good level of education; $22.4 \%$ have had an abortion; $43.5 \%$ went to the emergency room (ER) during pregnancy; $42.1 \%$ had some complications during pregnancy; $2.0 \%$ of puerperal women needed ICU admission in the postpartum period (Table 1).

Table 1 - Distribution of pregnant women according to sociodemographic and obstetric characteristics, São Paulo, São Paulo, Brazil, 2019

\begin{tabular}{|c|c|c|}
\hline Variable & $\mathbf{n}$ & $\%$ \\
\hline \multicolumn{3}{|l|}{ Age (years) } \\
\hline$<30$ & 218 & 13.8 \\
\hline $30-34$ & 380 & 24.1 \\
\hline $35-39$ & 731 & 46.4 \\
\hline $40-44$ & 230 & 14.6 \\
\hline 45 and older & 15 & 0.9 \\
\hline \multicolumn{3}{|l|}{ Education } \\
\hline Elementary school & 6 & 0.38 \\
\hline High school* & 179 & 11.4 \\
\hline Higher education* & 1001 & 63.8 \\
\hline Graduate degree* & 382 & 24.4 \\
\hline No information & 6 & 0.4 \\
\hline \multicolumn{3}{|l|}{ Origin } \\
\hline São Paulo & 1086 & 69.0 \\
\hline Rio de Janeiro & 209 & 13.3 \\
\hline Minas Gerais & 66 & 4.2 \\
\hline Pernambuco & 52 & 3.3 \\
\hline Bahia & 47 & 3.0 \\
\hline Federal District & 39 & 2.5 \\
\hline Others ${ }^{* * *}$ & 42 & 4.8 \\
\hline \multicolumn{3}{|l|}{ Previous abortions } \\
\hline No & 1222 & 77.6 \\
\hline Yes & 352 & 22.4 \\
\hline \multicolumn{3}{|c|}{ 'Intercurrence during pregnancy } \\
\hline No & 911 & 57.9 \\
\hline Yes & 663 & 42.1 \\
\hline
\end{tabular}

Note: *Complete/incomplete; ** Lato sensu and Stricto sensu; Alagoas, Amazonas, Amapá, Ceará, Espírito Santo, Goiás, Mato Grosso do Sul, Mato Grosso, Paraíba, Paraná, Rondônia, Roraima, Rio Grande do Sul, Santa Catarina.

Health-related data showed that pregnant women rated their health as good (96.9\%), planned pregnancy (73.6\%), were sedentary $(66.2 \%)$ and never gave birth (57.6\%). The analysis of habits showed that $92.3 \%$ of pregnant women had never smoked and $6.8 \%$ were former smokers. Only $0.9 \%$ reported being smokers during pregnancy and $10.8 \%$ reported having the habit of consuming alcoholic beverages.

Analysis of emotional aspects in relation to the current pregnancy showed that pregnant women reported mainly joy (92.9\%) and anxiety (5.7\%). Moreover, $97.8 \%$ reported feeling excited, $40.7 \%$ more emotional (crying more than before) and 33.9\% more irritated.

Regarding the diet, $92.0 \%$ reported eating normally and $7.7 \%$ reported reduced appetite. Most pregnant women reported working normally during pregnancy $(86.7 \%)$, many reported sleep disorders (37.4\%) fatigue (45.0\%).

At the beginning of the program, there was a predominance of preference for normal delivery (43.1\%) and cesarean section (35.7\%). Part of pregnant women, however, did not know how to inform the preference for type of delivery (21.2\%) at the beginning of the program. At the end of the program, $71.5 \%$ of pregnant women said they planned to have a cesarean delivery and $28.5 \%$ had a normal delivery, but $82.5 \%$ had a cesarean delivery and $17.5 \%$ had a normal delivery. Among the 
participants, $98.2 \%$ reported that the program was an important support during pregnancy.

We analyzed the relationship between the number of contacts of the pregnant woman with the program and the type of delivery, the complications, the search for the ER during pregnancy and ICU admission in the postpartum period. Pregnant women who went to the ER during pregnancy had significantly more contacts with the program, but there was no association between the number of contacts and the other variables analyzed (Table 2).

Table 2 - Relationship between the number of contacts with the program, type of delivery, complications, going to the emergency room and hospitalization in Intensive Care Units, São Paulo, São Paulo, Brazil, 2019

\begin{tabular}{lcc}
\hline Variable & $\begin{array}{c}\text { Number of } \\
\text { contacts }\end{array}$ & p value* \\
\hline Type of delivery & & 0.194 \\
$\quad$ Caesarean section & 9.19 & \\
$\quad$ Forceps & 9.00 & \\
$\quad$ Normal & 9.68 & \\
Intercurrence & & 0.057 \\
$\quad$ Yes & 9.08 & \\
$\quad$ No & 9.41 & \\
Emergency room during pregnancy & & $<0.001^{*}$ \\
$\quad$ Yes & 9.68 & \\
$\quad$ No & 8.95 & \\
Calls to the emergency room during & & $<0.001^{* *}$ \\
pregnancy & & \\
$\quad$ None of the time & 8.95 & \\
$\quad$ Once & 9.55 & \\
$\quad$ Twice & 9.87 & \\
$\quad$ Three times & 9.01 & \\
$\quad 4$ times or more & 10.02 & \\
Went to the Postpartum Intensive Care Unit & & 0.933 \\
$\quad$ Yes & 9.65 & \\
$\quad$ No & 9.26 & \\
\hline Note: *Wilcoxon-Mann-Whitney ( $p<0.001) *{ }^{* * K r u s k a l-W a l l i s ~}(p<0.001)$. &
\end{tabular}

The possible relationship between the type of delivery, age and BMI was also analyzed. Cesarean delivery was found to be associated with higher age and BMI (Table 3).

Table 3 - Association between type of delivery, age, and Body Mass Index, São Paulo, São Paulo, Brazil, 2019

\begin{tabular}{lcc}
\hline Variable & Type of delivery & $\boldsymbol{p}$ value* \\
\hline Age (years) & Caesarean section & \\
35.1 & Normal & $<\mathbf{0 . 0 0 1 *}$ \\
34.3 & Caesarean section & \\
Body Mass Index & Normal & $<\mathbf{0 . 0 0 1 * *}$ \\
27.4 & & \\
25.9 & Note: ${ }^{*}$ Wilcoxon-Mann-Whitney $(p<0.001)$; ${ }^{*}$ Brunner-Munzel $(p<0.001)$. &
\end{tabular}

The type of delivery was significantly associated with the practice of physical exercises during pregnancy. Normal delivery was more frequent among women who practiced exercise during pregnancy $(\mathrm{p}<0.001)$.

ICU admission was associated with older age and higher BMI (Table 4). The other variables analyzed were not associated with ICU admission. Analysis of the search for the ER during pregnancy showed that the women who went to the ER were significantly younger $(p<0.001)$. BMI, however, was not associated with the search for the ER during pregnancy (Table 4).
Table 4 - Relationship between age. Body Mass Index. Intensive Care Unit admission and going to the emergency room during pregnancy, São Paulo, São Paulo, Brazil, 2019

\begin{tabular}{|c|c|c|c|c|}
\hline Variable & $\begin{array}{l}\text { Intensive Care } \\
\text { Unit Admission }\end{array}$ & $p$ value & $\begin{array}{c}\text { Calls to the } \\
\text { Emergency } \\
\text { Room }\end{array}$ & $p$ value \\
\hline Age (years) & & $<0.001 * *$ & & $<0.001 *$ \\
\hline 38.2 & Yes & & 34.5 & \\
\hline 34.3 & No & & 35.4 & \\
\hline Body Mass Index & & $<0.001 *$ & & 0.143 \\
\hline 28.6 & Yes & & 27.4 & \\
\hline 27.1 & No & & 26.9 & \\
\hline
\end{tabular}

We also sought to identify possible association between emotional variables, life habits and the search for the ER during pregnancy. Pregnant women who reported insecurity and fear, who cried more frequently, who reported more tiredness/fatigue and who had difficulty working were significantly more to the ER during pregnancy (Table 5).

Table 5 - Relationship between going to the emergency room during pregnancy and emotional variables and lifestyle habits, São Paulo, São Paulo, Brazil, 2019

\begin{tabular}{|c|c|c|c|c|c|}
\hline \multirow{3}{*}{ Variable } & \multicolumn{4}{|c|}{$\begin{array}{l}\text { Went to the emergency } \\
\text { room during pregnancy }\end{array}$} & \multirow{3}{*}{$p$ value } \\
\hline & \multicolumn{2}{|c|}{ No } & \multicolumn{2}{|c|}{ Yes } & \\
\hline & $\mathbf{n}$ & $\%$ & $\mathbf{n}$ & $\%$ & \\
\hline Current pregnancy feeling & & & & & $0.033^{*}$ \\
\hline Joy & 822 & 56.9 & 622 & 43.1 & \\
\hline Anxiety & 49 & 55.1 & 40 & 44.9 & \\
\hline Insecurity & 05 & 45.5 & 6 & 54.5 & \\
\hline Fear & 01 & 11.1 & 8 & 88.9 & \\
\hline Sadness & - & - & 1 & 100.0 & \\
\hline Feel lively & & & & & 0.790 \\
\hline No & 19 & 54.3 & 16 & 45.7 & \\
\hline Yes & 868 & 56.6 & 667 & 43.4 & \\
\hline Feel emotional & & & & & $0.013^{*}$ \\
\hline No & 545 & 59.1 & 377 & 40.9 & \\
\hline Cries more than before & 337 & 52.7 & 302 & 47.3 & \\
\hline Cries all the time & 02 & 33.3 & 04 & 66.7 & \\
\hline Cannot cry & 03 & 100.0 & - & - & \\
\hline Feel irritated & & & & & 0.149 \\
\hline No & 597 & 58.0 & 432 & 42.0 & \\
\hline More than before & 287 & 53.9 & 245 & 46.1 & \\
\hline Not as much as before & 01 & 50.0 & 01 & 50.0 & \\
\hline All the time & 02 & 28.6 & 05 & 71.4 & \\
\hline Feel tired & & & & & $0.036^{*}$ \\
\hline No & 509 & 59.1 & 352 & 40.9 & \\
\hline More than before & 358 & 54.4 & 300 & 45.6 & \\
\hline When doing anything & 19 & 41.3 & 27 & 58.7 & \\
\hline Too much to do anything & 1 & 33.3 & 02 & 66.7 & \\
\hline Work normally & & & & & $0.018^{* *}$ \\
\hline Yes & 89 & 58.1 & 569 & 41.9 & \\
\hline Need extra effort & 05 & 38.5 & 08 & 61.4 & \\
\hline Too much effort & 01 & 25.0 & 03 & 75.0 & \\
\hline Cannot work like before & 78 & 50.0 & 78 & 50.0 & \\
\hline Cannot work & 14 & 38.9 & 22 & 61.1 & \\
\hline Eat normally & & & & & 0.294 \\
\hline Yes & 826 & 57.2 & 619 & 42.8 & \\
\hline Lower appetite & 54 & 48.6 & 57 & 51.4 & \\
\hline Much lower appetite & 06 & 54.6 & 05 & 45.4 & \\
\hline Lost appetite & 01 & 33.3 & 02 & 66.7 & \\
\hline Smoker & & & & & 0.728 \\
\hline No & 817 & 56.2 & 636 & 43.8 & \\
\hline Former smoker & 63 & 58.9 & 44 & 41.1 & \\
\hline Yes & 09 & 64.3 & 05 & 35.7 & \\
\hline
\end{tabular}


Table 5 (concluded)

\begin{tabular}{|c|c|c|c|c|c|}
\hline \multirow{3}{*}{ Variable } & \multicolumn{4}{|c|}{$\begin{array}{l}\text { Went to the emergency } \\
\text { room during pregnancy }\end{array}$} & \multirow{3}{*}{$p$ value } \\
\hline & \multicolumn{2}{|c|}{ No } & \multicolumn{2}{|c|}{ Yes } & \\
\hline & $\mathbf{n}$ & $\%$ & $\mathbf{n}$ & $\%$ & \\
\hline Drink alcoholic beverages & & & & & 0.510 \\
\hline Never & 791 & 56.3 & 613 & 43.7 & \\
\hline Up to 3 doses & 91 & 58.3 & 65 & 41.7 & \\
\hline From 4 to 7 doses & 05 & 41.7 & 07 & 58.3 & \\
\hline More than 7 doses & 02 & 100.0 & - & - & \\
\hline Drink alcoholic beverages & & & & & 0.510 \\
\hline Never & 791 & 56.3 & 613 & 43.7 & \\
\hline Up to 3 doses & 91 & 58.3 & 65 & 41.7 & \\
\hline From 4 to 7 doses & 05 & 41.7 & 07 & 58.3 & \\
\hline More than 7 doses & 02 & 100.0 & - & - & \\
\hline $\begin{array}{l}\text { Physical activity during } \\
\text { pregnancy }\end{array}$ & & & & & 0.682 \\
\hline No & 553 & 56.1 & 433 & 43.9 & \\
\hline Yes & 336 & 57.1 & 252 & 42.9 & \\
\hline Sleep pattern & & & & & 0.426 \\
\hline Normal & 571 & 58.1 & 412 & 41.9 & \\
\hline $\begin{array}{l}\text { Do not sleep like they } \\
\text { used to }\end{array}$ & 240 & 53.7 & 207 & 46.3 & \\
\hline Difficulty returning to sleep & 29 & 56.9 & 22 & 43.1 & \\
\hline Unable to go back to sleep & 47 & 53.4 & 41 & 46.6 & \\
\hline
\end{tabular}

Nota: *Teste Exato de Fisher; **Qui-Quadrado de Pearson $(p<0,005)$.

\section{DISCUSSION}

The characterization of the sample showed that most of pregnant women included in the program were aged 35 and over had a high level of education and were overweight, which reflects the female behavioral change over the past decades. Women in Brazil and in the world have opted for greater dedication to studies and professional life, are inserted in positions of professional leadership and live with competitiveness and greater stress overload, in challenging work environments, postponing more and more motherhood, mainly in the most favored social classes ${ }^{(12)}$.

Older mothers are more prepared for pregnancy, whether physical, psychological, emotional, relational, social or financial. They are women who can have healthier children with better developmental capacities ${ }^{(13)}$. On the other hand, women may feel inadequate in relation to age and pregnancy, attitudes that can trigger other factors in addition to those already commonly associated with the risk label, such as insecurity and anxiety, impairing the normal evolution of this period ${ }^{(13)}$.

Advanced maternal age showed an association with cesarean delivery, as observed in other studies ${ }^{(14-15)}$. However, the initial preference of pregnant women for normal delivery in the present study occurred in $43.1 \%$ of pregnant women and only $17.3 \%$ had a normal delivery.

The highest proportion of pregnant women in the study was between 35 and 39 years old and the average age associated with cesarean delivery was 35.1 years. Studies suggest that mothers aged $\geq 40$ years may have higher risks of gestational diabetes, elective cesarean section and placenta previa, compared to younger mothers. A recent study showed that women $\geq 45$ years old were at increased risk for obstetric complications such as pre-eclampsia, prolonged hospitalization and premature rupture of membranes ${ }^{(15)}$.
In 2018, WHO recommended using non-clinical interventions to reduce the number of cesarean sections worldwide through health education, with an emphasis on topics about fear and anxiety related to childbirth, the natural process and individual reactions, stages, hospital routines and forms of pain relief ${ }^{(16)}$.

In this educational process, the need to pay greater attention to the gaps identified by women themselves as related to women's choices such as home birth and vaginal delivery after cesarean section is highlighted. The importance of recognizing childbirth as an important and valuable life experience for the people involved is stressed ${ }^{(16)}$.

Analysis of the "Futura Mamãe" Program database also showed a significant impact of the average BMI profile of overweight (27.2) in the first trimester of pregnancy and a higher risk of cesarean delivery, with more than $60 \%$ of overweight women/ obesity. High BMI at the beginning of pregnancy and excessive gestational weight gain have been associated with negative obstetric outcomes and increased risk of complications $s^{(10,17-19)}$.

A study that described the obstetric outcome of overweight/ obese women concluded that pre-gestational overweight/obesity women had an increased risk of developing pre-eclampsia (OR 3.3; 95\% Cl 1.1-9.9; $p=0.03$ ) and there was a trend towards an association between type of surgical delivery or forceps and overweight/obesity (OR 1.8; 95\% Cl 0.9-3.5; $\mathrm{p}=0.04)^{(17)}$.

Obesity was also associated with an increased risk of developing thrombosis, gestational diabetes, increased blood pressure and pre-eclampsia, mental health problems during pregnancy and after childbirth ${ }^{(18)}$. Fetal risks associated with maternal obesity include miscarriage, neural tube defects, fetal macrosomia, fetal deaths and increased need for ultrasound exams ${ }^{(18)}$.

A research conducted in southern Brazil that analyzed the impact of BMl at the beginning of pregnancy and gestational weight gain on pregnancy outcome concluded that the higher the BMI in the first trimester and the weight gain during pregnancy, the greater the risk of surgical delivery. However, there was no relationship between BMI and gestational weight gain with increased risk of hypertension and diabetes ${ }^{(19)}$.

In the present study, physical activity during pregnancy was associated with a significantly higher proportion of normal deliveries (49.6\%) than cesarean deliveries (34.7\%), similarly to other studies ${ }^{(20-21)}$. Sedentary pregnant women during pregnancy had an increased risk of having an emergency cesarean delivery and need for a vacuum extractor for vaginal deliveries ${ }^{(21)}$.

Exercise during pregnancy was associated with reduced risk of cesarean sections, particularly emergency ${ }^{(20)}$. The greatest risk reduction was related to exercise more than 5 times during 17 weeks $(-2.2 \%)$ and 30 weeks of gestation $(-3.6 \%)$ compared with sedentary pregnant women $(p<0.001)$. High impact exercises between 17 and 30 weeks of gestation were associated with reduced risk of cesarean section $(-3.0 \%$ and $-3.4 \%$, respectively) ${ }^{(20)}$.

In the present study, a significant association was found between emotional variables, some lifestyle habits and the search for ER during pregnancy. Pregnant women who reported insecurity and fear, who cried more frequently, who reported more tiredness/fatigue and who had difficulty working were significantly more at the ER during pregnancy. 


\section{Study limitations}

Secondary data from a company that offered the intervention were used and the sample included pregnant women with a high level of education and access to private health services, which does not represent the average profile of Brazilian women and makes generalizations difficult. Another limitation is the design of the study, of the retrospective case series type, with secondary data, which does not allow establishing causal relationships between variables, only associations.

\section{Contributions to health}

Among the study's contributions, the potential of telemedicine interventions for pregnant women at risk stands out, which can contribute to stimulate healthy lifestyle habits, such as the practice of physical activity during pregnancy, in addition to emotional support for pregnant women. These measures can impact on normal birth rates and more rational use of health services.

\section{CONCLUSION}

The high-risk pregnant women were highly educated and aged, with a predominance of overweight. The youngest, who had more contacts with the intervention, who reported fear, insecurity, greater emotionality, fatigue and greater difficulty for work, sought more often the ER during pregnancy. Older age, physical inactivity and overweight/obesity were factors associated with cesarean delivery. Normal delivery was more frequent among women who exercised during pregnancy. ICU admission in the postpartum period was associated with higher age and BMI.

These data allow planning interventions to improve the health conditions of pregnant women at risk, with a view to increasing the rate of normal births and reducing complications.

\section{ACKNOWLEDGMENTS}

We would like to thank AzimuteMed for the partnership in developing this study.

\section{REFERENCES}

1. World Health Organization (WHO). WHO recommendations on antenatal care for a positive pregnancy experience [Internet]. Geneva: WHO; 2016 [cited 2020 Mar 29]. Available from: https://apps.who.int/iris/bitstream/handle/10665/250796/9789241549912-eng.pdf

2. United Nations. Transforming our world: the 2030 Agenda for Sustainable Development 2015: Resolution adopted by the General Assembly on 25 September 2015[Internet]. United Nations General Assembly, Seventieth session. New York (NY): United Nations; 2015 [cited 2020 Mar 29]. Available from: https://sustainabledevelopment.un.org/content/documents/21252030\%20Agenda\%20for\%20Sustainable\%20Development\%20web.pdf

3. World Health Organization (WHO). Trends in maternal mortality: 2000 to 2017: estimates by WHO, UNICEF, UNFPA, World Bank Group and the United Nations Population Division. [Internet]. Geneva: World Health Organization; 2019 [cited 2020 Mar 29]. Available from: http:// documents.worldbank.org/curated/en/793971568908763231/pdf/Trends-in-maternal-mortality-2000-to-2017-Estimates-by-WHO-UNICEFUNFPA-World-Bank-Group-and-the-United-Nations-Population-Division.pdf

4. Souza JP. A mortalidade materna e os novos objetivos de desenvolvimento sustentável (2016-2030). Rev Bras Ginecol Obstet. 2015;37(12):549-51. https://doi.org/10.1590/SO100-720320150005526

5. Medeiros FF, Santos IDDL, Ferrari RAP, Serafim D, Maciel SM, Cardelli AAM. Acompanhamento pré-natal da gestação de alto risco no serviço público. Rev Bras Enferm. 2019;72 (suppl 3):204-11. https://doi.org/10.1590/0034-7167-2018-0425

6. Tomasi E, Fernandes PAA, Fischer T, Siqueira FCV, Silveira DSD, Thumé E, et al. Qualidade da atenção pré-natal na rede básica de saúde do Brasil: indicadores e desigualdades sociais. Cad Saúde Pública. 2017;33(3):e00195815. https://doi.org/10.1590/0102-311X00195815

7. Jacob LMS, Mafetoni RR, Figueira MCS, Lopes MHBM, Shimo AKK. Ações educativas para prevenção de complicações relacionadas à gestação. Rev Enferm Atual Derm. 2019;87:25. https://doi.org/10.31011/reaid-2019-v.87-n.25-art.197

8. Oliveira SCD, Fernandes AFC, Vasconcelos EMRD, Ximenes LB, Leal LP, Cavalcanti AMTS, et al. Efeito de uma intervenção educativa na gravidez: ensaio clínico randomizado em cluster. Acta Paul Enferm. 2018;31(3):291-98. https://doi.org/:10.1590/1982-0194201800041

9. Chaves AFL, Ximenes LB, Rodrigues DP, Vasconcelos CTM, Santos Monteiro JC, Oriá MOB. Intervenção telefônica na promoção da autoeficácia, duração e exclusividade do aleitamento materno: estudo experimental randomizado controlado. Rev Latino-Am Enfermagem. 2019;27:e3140. https://doi.org/10.1590/1518-8345.2777-3140

10. Ministério da Saúde (BR). Secretaria de Atenção à Saúde. Departamento de Ações Programáticas Estratégicas. Gestação de alto risco: manual técnico[Internet]. Brasília: Ministério da Saúde; 2012 [cited 2020 Oct 23]. Available from: http://bvsms.saude.gov.br/bvs/ publicacoes/manual_tecnico_gestacao_alto_risco.pdf

11. Ministério da Saúde (BR). Secretaria de Atenção à Saúde. Manual de acolhimento e classificação de risco em obstetrícia[Internet]. Brasília: Ministério da Saúde; 2018 [cited 2020 Oct 23]. Available from: https://portaldeboaspraticas.iff.fiocruz.br/wp-content/uploads/2018/10/ Manual_obstetr\%C3\%ADcia-final-1.pdf

12. Riad S. Under the desk: on becoming a mother in the workplace. Cult Organ. 2007;13(3):205-22. https://doi. org/10.1080/14759550701486522

13. Aldrighi JD, Wal ML, Souza SRRK, Cancela FZV. The experiences of pregnant women at an advanced maternal age: an integrative review. Rev Esc Enferm USP. 2016;50(3):509-18. https://doi.org/10.1590/S0080-623420160000400019 
14. Ojule JD, Ibe VC, Fiebai PO. Pregnancy outcome in elderly primigravidae. Ann Afr Med. 2011;10(3):204-8. https://doi. org/10.4103/1596-3519.84699

15. Nieto MC, Barrabes EM, Martínez SG, Prat MG, Zantop BS. Impact of aging on obstetric outcomes: defining advanced maternal age in Barcelona. BMC Pregnancy Childbirth. 2019;19:342. https://doi.org/10.1186/s12884-019-2415-3

16. World Health Organization (WHO). WHO recommendations non-clinical interventions to reduce unnecessary caesarean sections[Internet]. Geneva:WHO; 2018 [cited 2020 Mar 29]. Available from: https://apps.who.int/iris/bitstream/handle/10665/275377/9789241550338-eng.pdf

17. Seabra G, Padilha PC, Queiroz JA, Saunders C. Sobrepeso e obesidade pré-gestacionais: prevalência e desfechos associados à gestação. Rev Bras Ginecol Obstet. 2011;33(11):348-53. https://doi.org/10.1590/S0100-72032011001100005

18. Yang Z, Phung H, Freebairn L, Sexton R, Raulli A, Kelly P. Contribution of maternal overweight and obesity to the occurrence of adverse pregnancy outcomes. Aust N Z J Obstet Gynaecol 2019;59:367-74. https://doi.org/10.1111/ajo.12866

19. Gonçalves CV, Mendoza-Sassi RA, Cesar JA, Castro NBD, Bortolomedi AP. Índice de massa corporal e ganho de peso gestacional como fatores preditores de complicações e do desfecho da gravidez. Rev Bras Ginecol Obstet. 2012;34(7):304-9. https://doi.org/10.1590/ S0100-72032012000700003

20. Owe KM, Nystad W, Stigum H, Vangen S, Bø K. Exercise during pregnancy and risk of cesarean delivery in nulliparous women: a large population-based cohort study. Am J Obstet Gynecol. 2016;215(6):791.e1-13. https://doi.org/10.1016/j.ajog.2016.08.014

21. Nielsen EM, Andersen PK, Hegaard HK, Juhl M. Mode of delivery according to leisure time physical activity before and during pregnancy: a multicenter cohort study of low-risk women. J Pregnancy. 2017:ID6209605. https://doi.org/10.1155/2017/6209605 